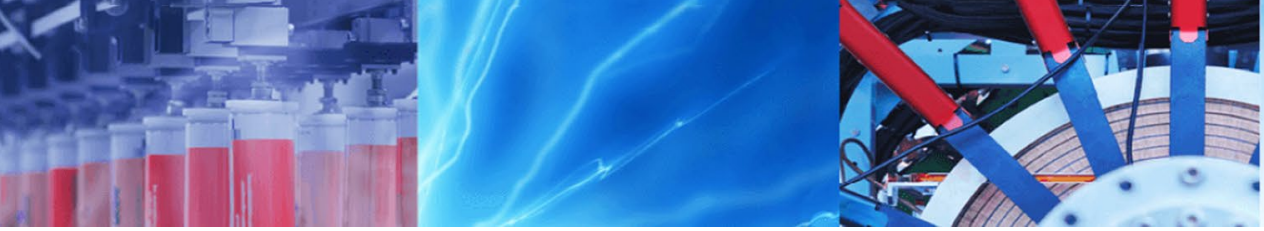

Research Article

\title{
Lean and agile practices to improve the performance of filling process via simulation and data envelopment analysis
}

\author{
Abbas Al-Refaie ${ }^{1}$ (D) Ghaleb Abbasi ${ }^{1} \cdot$ Heba Al-shalaldeh ${ }^{2}$
}

(c) Springer Nature Switzerland AG 2019

\begin{abstract}
This research aims at identifying the appropriate lean and/or agile practice(s) to improve the performance of filling process in a pharmaceutical industry. Initially, the As-Is simulation model of production processes was built and then run to estimate the process's output measures; averages of input bottle, work in process, waiting time, cycle time, and output bottles. The simulation results showed overall equipment effectiveness (OEE) score for some production processes were smaller than the recommended minimum world-class values. Consequently, agile and/or lean practices were utilized to generate nine To-Be improvement scenarios. Simulation was run to evaluate the process's output measures and OEE score for each scenario. Finally, the slack based model (SBM) in data envelopment analysis was adopted to determine the best improvement alternative. The SBM results revealed that the lean practice "adding another head to the labeler machine" is the best alternative that may result in anticipated improvement in the OEE by $13.5 \%$. In conclusion, the lean and/or agile practices can result in significant savings in production and quality costs.
\end{abstract}

Keywords Agile · Lean · OEE · Data envelopment analysis · Simulation · Slack based model

\section{Introduction}

To survive and prosper in today's competitive environment of unpredictable changes, pharmaceuticals industry should continually enhance performance of existing manufacturing processes to respond effectively to changing markets and reduce efficiently non-value added activities.

The agile and lean manufacturing have been found effective practices for achieving such goals [1, 2]. The objective of agile manufacturing is to respond to rapidly changing markets, global competitive pressure, decreasing new product time to market, and increasing value of information or service $[3,4]$. Agile practices include adding resources and buffers, outsourcing, and utilize existing machine for more time [5-8]. On the other hand, lean manufacturing employs the advantages of mass production in concert with the principles of Just-in-time and elimination of waste (non-value added activities) in order to reduce total production costs $[9,10]$. Lean practices focus on cost reduction by improving quality and throughput [11-13], including purchasing new machines, and performing rework $[14,15]$. In practice, a combination of agile and lean practices might be appropriate, or so called "leagile" [16-19]. The leagile concept combines lean strategy with agile strategy and realizes the quick response to the changeable demand and optimizes cost, time, and profitability.

Once lean, agile, or leagile practices have been applied, there is a need to adopt performance measures that can provide a very valuable insight of how effectively the manufacturing process is running. The Overall Equipment Effectiveness (OEE) is a lean business metric tool commonly used to measure three critical manufacturing performance indicators (availability, quality, performance) [20-25].

Abbas Al-Refaie, abbas.alrefai@ju.edu.jo | 'Department of Industrial Engineering, University of Jordan, Amman 11942, Jordan. ${ }^{2}$ Industrial Engineering, University of Jordan, Amman, Jordan.

SN Applied Sciences (2019) 1:1131 | https://doi.org/10.1007/s42452-019-1199-4

Received: 30 March 2019 / Accepted: 29 August 2019 / Published online: 31 August 2019 
In this research, the OEE scores are compared with the world class values to determine the machines of the filling processes that need improvement. Then, each of agile and lean alternatives is treated as a decision making unit (DMU) with multiple inputs and multiple outputs. To identify the best one, an appropriate data envelopment analysis (DEA) technique will be employed. Typically, DEA a nonparametric for assessing the relative efficiency of a set of homogeneous units, usually referred to as decision making units (DMUs) that uses multiple inputs to produce multiple outputs [30-32]. Slack-based method (SBM) is a DEA technique that evaluates DMU's efficiency evaluation invariant to the units of measure used for the different inputs and outputs; i.e., dimension free or units invariant [26-31]. In this research, each improvement scenario will be treated as a decision making unit (DMU).

Generally, the pharmaceutical industry is an important element of health care system that demands strict adherence to safety and quality standards. Therefore, it is crucial that pharmaceutical manufacturing machine comply with good manufacturing practices. One of the important processes in this industry is the filling processes. A study of a pharmaceutical industry in Jordan showed that existing filling processes suffer long cycle time with low production rates, long average waiting times, high average number waiting in queue, and thereby a low overall equipment effectiveness (OEE). The objectives of this research is, therefore, twofold: (1) assessing improvement scenarios of lean and agile practices to enhance performance of the filling processes and (2) identifying the best alternative using appropriate multiple-criteria decision-making technique. The results of this research enables process engineering identifying the best improvement practice that enhances performance and saves costly production and quality costs. The remaining of this paper including the introduction is outlined in the following sequence. Section two presents research methodology. Section three conducts improvement of filling processes using agile and lean practices. Section four presents research results and discussion. Finally, conclusions are made in section five.

\section{Literature review}

Lean manufacturing has been examined in several research studies. For example, Sohal and Egglestone [32] examined lean production among Australian organizations. Bonavia and Marin [33] conducted an empirical study of lean production in the ceramic tile industry in Spain. Mahapatra and Mohanty [34] carried out an empirical study on lean manufacturing in continuous process industry. Wong et al. [35] performed a study on lean manufacturing implementation in the Malaysian electrical and electronics industry. Ferdousi and Ahmed [36] conducted manufacturing performance improvement through lean production in Bangladeshi garment firms. Yogesh et al. [37] applied lean in electronics and electrical manufacturing industry in India. Devakim and Jayanthi [38] examined barriers to implementation of lean principles in the Indian construction industry. Khlat et al. [39] studied lean manufacturing: implementation and assessment in the Lebanese pharmaceutical industry. Hu et al. [40] reviewed literature on lean implementation within small and medium sized firms. Kafuku [41] investigated factors for effective implementation of lean manufacturing practice in selected industries in Tanzania.

Further, several studies examined the implementation of agile manufacturing. For instance, Sharp et al. [7] assessed agile manufacturing in the UK industry. Gunasekaran et al. [42] investigated the application of agile manufacturing in an aerospace company. VázquezBustelo [43] presented case studies on agile manufacturing in Spain. Francisco and Manuela [44] explored agile methods in construction small \& medium enterprises: a case study. Zhang [45] presented case studies of an agility taxonomy. Iqbal et al. [46] examined the relationship among agile manufacturing, total quality management, just-in-time and firm performance in apparel export industry of Pakistan. Fritzsche [47] presented implications of agile manufacturing in the automotive industry for order management in the factories-evidence from the practitioner's perspective.

It is noticed that some of the previous work focused on developing and evaluating conceptual and exploratory models on lean and agile manufacturing. Other studies applied lean and/agile practices to improve performance. This research, however, proposes and assesses the effectiveness of adopting alternatives of lean/agile practices using simulation, which helps decision makers in determining the effect of implementing each practice on processes' performance before physical changes are made. Moreover, it measures the improvement in the output measures of production line's processes in each alternative, which helps in early identification of potential problems in subsequent processes. Finally, it utilizes the DEA approach to identify the best alternative other than acceptable solution.

\section{Research methodology development and implementation}

\subsection{Research methodology development}

The research methodology is divided into three phases as depicted in Fig. 1 and described as follows: 
Fig. 1 Research methodology

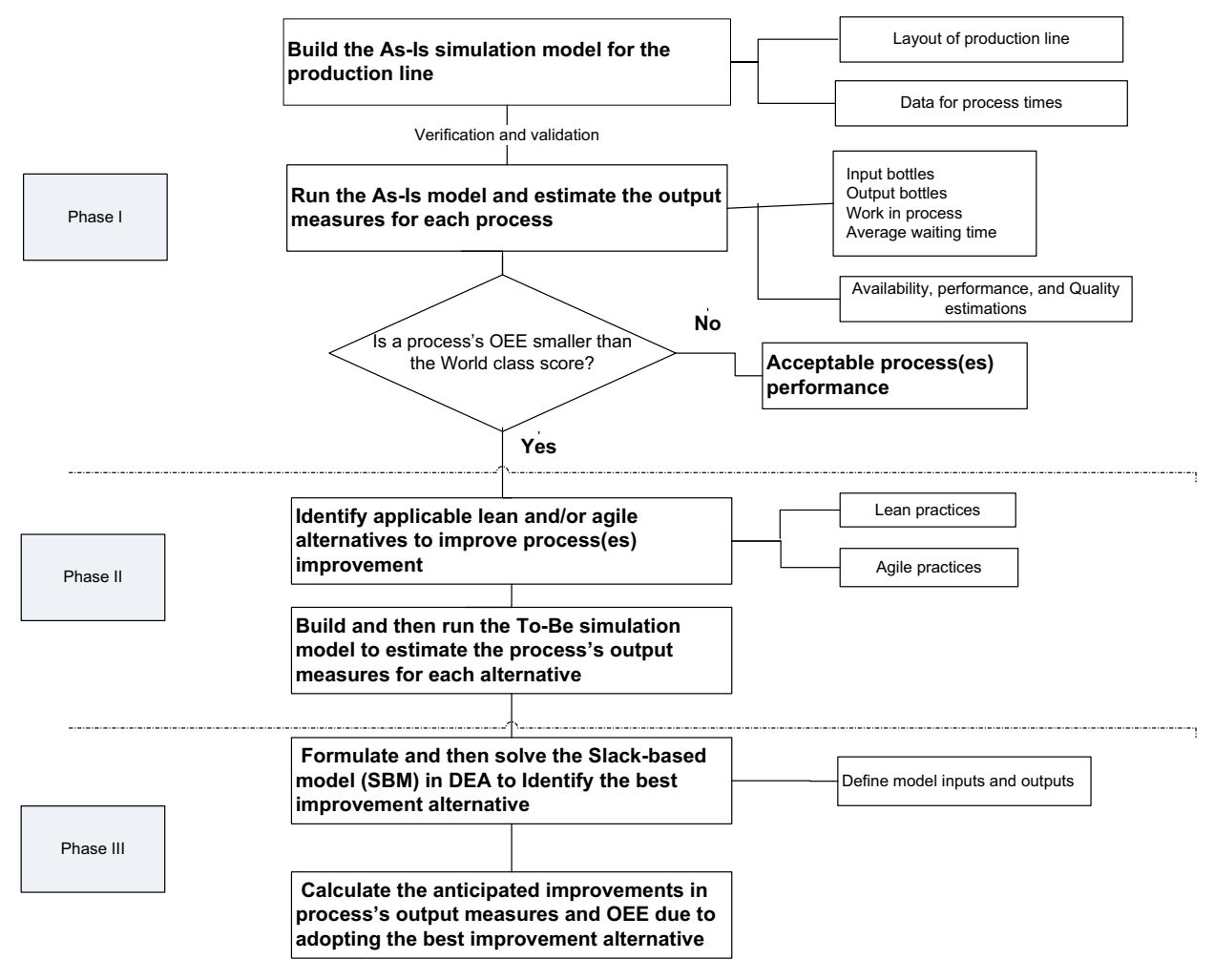

\subsubsection{Phase I: Describe the filling processes and build the As-Is simulation model}

In this phase, the layout of the production processes is constructed. Then, the important information regarding processing times, moving times, and inspection stages are collected. Finally, the As-Is simulation model is developed at the current process conditions and then run to estimate the output measures of process performance; measures; cycle time, average waiting time, and average of filled bottles. In addition, the OEE measure is calculated for each process to identify the processes that needs improvement. Typically, the OEE measure is calculated using Eq. (1).

$O E E=A \times P \times Q$

where $A, P$, and $Q$ denote availability, performance, and quality, respectively. Figure 2 illustrates the required times for OEE calculation in a particular production system.

The components of the OEE measure are calculated as follows. The availability $(A)$ is given as:

$A=\frac{T_{\text {operating }}}{T_{\text {planned production }}} \times 100 \%=\frac{\text { Run time }}{\text { Run time }+ \text { stop time }} \times 100 \%$

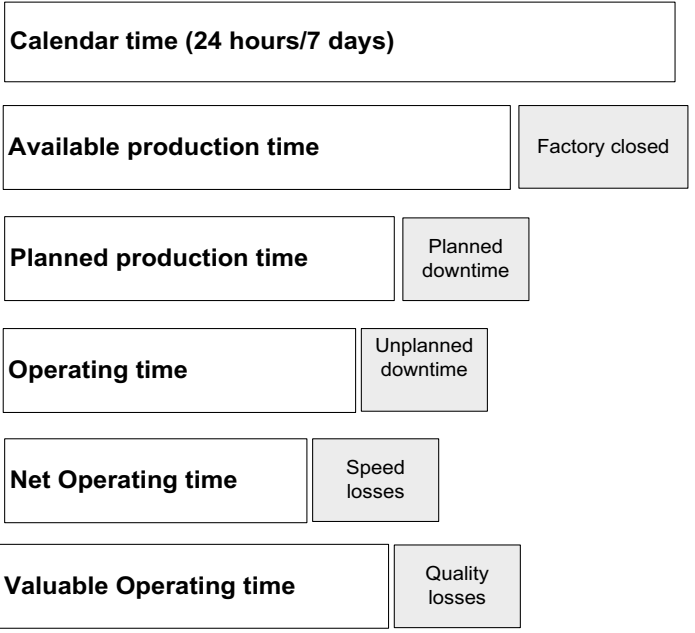

Fig. 2 Times and losses considered in OEE

Further, the performance $(P)$ is estimated using Eq. (3).

$P=\frac{T_{\text {net operating }}}{T_{\text {operating }}} \times 100 \%=\frac{\text { Ideal cycle time } \times \text { total count }}{\text { Run time }} \times 100 \%$ 
Finally, the quality $(Q)$ is calculated by Eq. (4).

$Q=\frac{T_{\text {valuable operating }}}{T_{\text {net operating }}} \times 100 \%=\frac{\text { Good count }}{\text { Total count }} \times 100 \%$

The obtained values are then compared with the world class values. Then, a process of OEE value smaller than the world class values is identified as key process that requires improvement.

\subsubsection{Phase II: Propose and assess lean/agile improvement alternatives (To-Be models)}

In this phase, several applicable alternatives based on lean and/or agile practice(s) will be introduced to the As-Is simulation models. Then, the To-Be simulation model is run to estimate the process's output measures. The number of To-Be simulation models is equal to the number of suggested alternatives.

\subsubsection{Phase III: Identify and implement the best improvement alternative}

This phase utilizes the slack-based model (SBM) to identify the best improvement alternative. The SBM is presented as follows. Each alternative for process improvement is treated as a decision making unit (DMU). Then, the process's output measures are divided into inputs and output for each DMU. In this research, the number of input bottles, average work in progress, average waiting time, and average cycle time are treated as inputs, whereas the number of output bottles and OEE are set as the outputs for each DMU. Consider a set of $n$ DMUs. For DMU $k$, let $y_{r k}(r=1, \ldots, s)$ denote the level of $r$ th output, and $x_{i k}(i=1, \ldots, m)$ the level of the ith input. Then, the optimal efficiency, $\rho *$, score can be obtained using input-oriented SBM as follows:

$$
\rho^{*}=\operatorname{Min} 1-\frac{1}{m} \sum_{i=1}^{m} \frac{s_{i}^{-}}{x_{i k}}
$$

Subject to:

$$
\begin{aligned}
& x_{i k}=\sum_{j=1}^{n} \lambda_{j} x_{i j}+s_{i}^{-} \quad i=1, \ldots, m \\
& y_{r k} \leq \sum_{j=1}^{n} \lambda_{j} y_{r j} \quad r=1, \ldots, s \\
& \lambda_{j}, s_{i}^{-} \geq 0 \quad j=1, \ldots, n ; \quad i=1, \ldots, m
\end{aligned}
$$

where $s_{i}^{-}$is slack variable. If the optimal efficiency, $\rho^{*}$, is equal to one, then the DMU is considered efficient; otherwise, it is inefficient. However, there sometimes exist multiple efficient DMUs. To discriminate between SBM efficient DMUs, the Super Slack-Based Model (Super-SBM) is used by introducing a positive scalar variable $t$ as follows:

$\theta^{*}=\operatorname{Min} t-\frac{t}{m} \sum_{i=1}^{m} \frac{s_{i}^{-}}{x_{i k}}$

Subject to:

$t+\frac{t}{s} \sum_{r=1}^{s} \frac{s_{r}^{+}}{y_{r k}}=1$

$\sum_{j=1, \neq k}^{n} \lambda_{j} x_{i j}+s_{i}^{-}=x_{i k} \quad i=1, \ldots, m$

$\sum_{j=1, \neq k}^{n} \lambda_{j} y_{r j}-s_{r}^{+}=y_{r k} \quad r=1, \ldots, s$

$\lambda_{j}, s_{i}^{-}, s_{r}^{+} \geq 0 \quad j=1, \ldots, n ; \quad i=1, \ldots, m ; \quad r=1, \ldots, s$

where $s_{i}^{+}$is slack variable. The super SBM model excludes the $\mathrm{DMU}_{k}$ under consideration and calculates its efficiency score using the inputs and outputs of the other DMUs. Solving the model, then the $\mathrm{DMU}_{j}$ that corresponds to larger $\theta^{*}$ will be set a lower rank.

\subsection{Research methodology application on filling processes}

\subsubsection{In phase I}

The layout of filling processes in a pharmaceutical industry is depicted as shown Fig. 3. Samples of the detailed layout are depicted in Fig. 4. Illustration of machine and conveyor charcteristics are shown in Fig. 5. The production line is described as follows. The unscramble process aligns and orients empty bottles correctly. Then, the blower process uses vacuum system to clean up the bottles from dirt. The Blower's inspection sensor (number 1 in the layout) removes incorrectly aligned bottles. Fillers consists of two identical Fillers $A$ and $B$, which are placed with the purpose of filling the bottles with predetermined amount of powder. Each filler contains two inspection sensors (numbered 2, 3 and 4, 5); called check weigher or load cell, sensor 2 and 4 are located before filling the bottle, to weigh the empty bottles, whereas 
Fig. 3 Layout of filling processes in a pharmaceutical industry

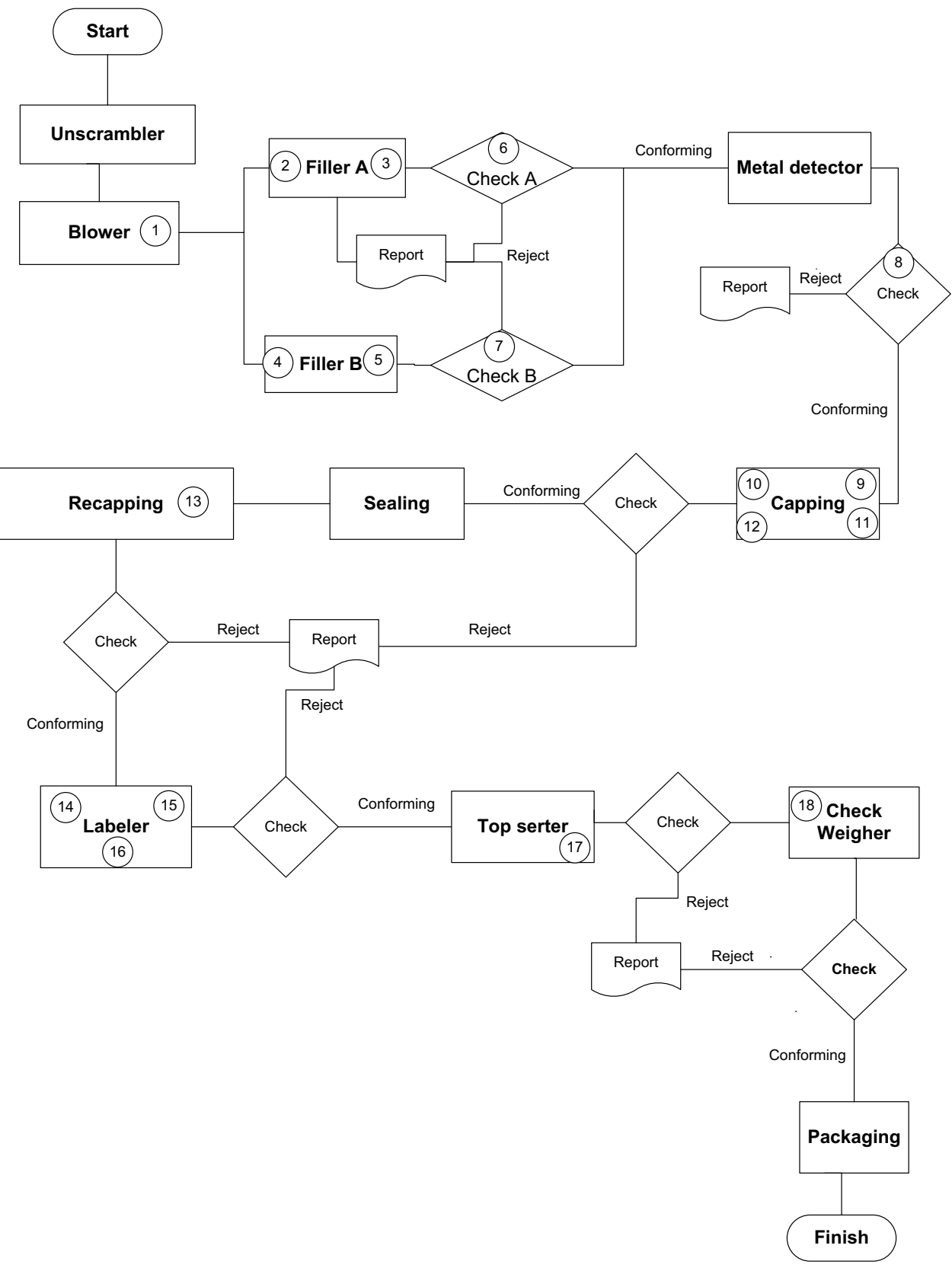

sensors 3 and 5 are located after filling the powder to weigh the bottles after being filled. The net weight of powder should be within a predetermined range many out of range weigh, the bottle will be rejected. Inspection sensors 6 and 7 reassure the rejection fillers capacity and processing time are 14 bottles and $7 \mathrm{~s}$, respectively. The bottles pass to metal detector, which radiates waves to detect any passing metal. Inspection sensor (8) rejects a bottle if it contains any metal this machine capacity is 1 bottles as well as its processing time is $0.0001 \mathrm{Sec}$. Then, capping process attaches caps to bottles. While, inspection sensor (9) orders a cap for each passing bottle, sensor (10) inspects if the cap positioned in the right place of the top of the bottle, sensor (11) makes sure that cap liner, the foil slice inside the cap, is available inside the cap, sensor (12) reassures the rejection from sensors (10 and 11). The sealing process follows to stick the cap liner to the top of bottle at high temperatures. Recapping process then adjusts the changes due to the exposure to high temperatures in sealing stage that leads to minor changes in the cap's dimensions may happen. Recapping share the same characteristics with the capping machine. Sensor (13) checks the tightness of the caps and rejects bottles if their cap is loose. Then, labeling process attaches labels to bottles. Sensor (14) orders a label for every passing bottle, sensor (15) inspects the 
Fig. 4 Samples of the detailed layout
Fig. 5 Sample of machine and conveyor characteristics
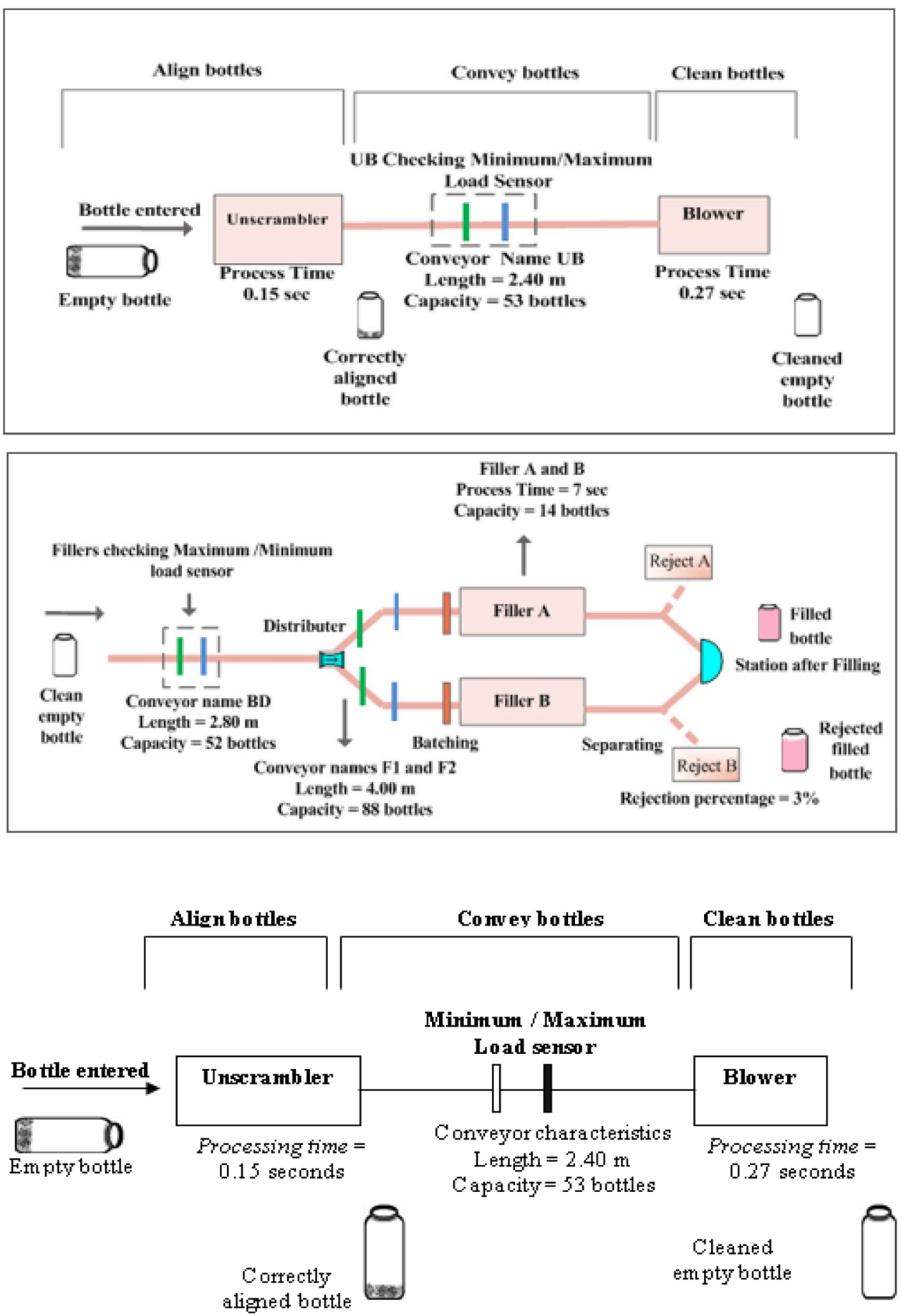

availability of the required mentioned, and sensor (16) reassures the rejection caused by sensor (15). Top serter process follows to stick the description of the medicine on the top of the bottles. Inspection sensor (17) rejects any bottle without a description placed on the bottle's top. Next, the check weigher process ensures the perfect fit and accurate weight result. Inspection sensor (18) check final range of weight, which must be between minimum and maximum ranges are $63.8 \mathrm{~g}$ and $68.7 \mathrm{~g}$, respectively. Finally, bundling and stretch banding processes package 24 bottles together by using a plastic cover, to be ready for finial package by the operator at the packaging area.

Minimum/Maximum load sensors are located between each two machines. It works according to the number of accumulated bottles in the queue, following these conditions. For illustration, the operating mechanism of the Minimum/Maximum load sensors in the 
filling line is illustrated in Fig. 6. If queue reaches only the minimum load sensor (i.e., a slight load on machine two occurs), then there is no need to keep working until the accumulation bottles exceed the minimum load sensor. If queue reaches the maximum load sensor; i.e., a heavy load on machine two occurs), then machine one needs to pause until machine two accomplish part of the queue. If (minimum load sensor $<$ queue $<$ maximum load sensor), then both machines will be working.

Then, the As-Is model is built at the current condition of the filling processes as also shown in Fig. 2. Motion and time study is then conducted to measure the characteristics of machines, load sensors, and conveyors. Data for filling processes were collected as summarized in Table 1. Conveyor speeds are identical and equal to (200 bottles/ min), but they vary in lengths and capacities (Table 2). The characteristics of conveyors and load sensors are displayed in Tables 3 and 4, respectively.

Under current machine conditions, simulation model was run for a shift length of one batch (390 $\mathrm{min}$ ) with two short breaks each of $15 \mathrm{~min}$ and a meal break of $60 \mathrm{~min}$. The down time is determined to be $0 \mathrm{~min}$. Simulation was run ten times, where the results showed that the values of standard deviations divided by the corresponding averages are very small $(<0.01)$ for all measured simulation outputs. Further, to validate simulation model the average

Fig. 6 Minimum/maximum load sensors

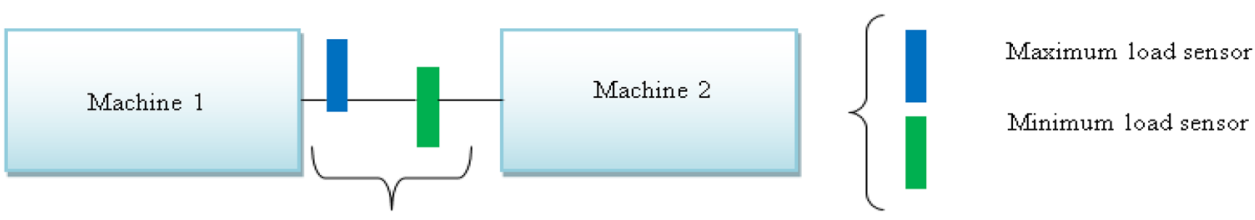

Table 1 Machine characteristics

\begin{tabular}{|c|c|c|c|c|c|c|c|}
\hline Machine & Processing time (s) & $\begin{array}{l}\text { Processing } \\
\text { time (bottles) }\end{array}$ & $\begin{array}{l}\text { Maximum } \\
\text { capacity (bot- } \\
\text { tle) }\end{array}$ & Input (bottle) & Output (bottle) & Rejected (bottle) & Reject (\%) \\
\hline Unscrambler & 0.15000 & 1 & 56 & 52,188 & 52,188 & 0.00 & 0.00 \\
\hline Blower & 0.27000 & 1 & 25 & 52,188 & 52,188 & 0.00 & 0.00 \\
\hline Filler $\mathrm{A}$ & 7.00000 & 14 & 14 & 52,188 & 51,196 & 992 & 1.90 \\
\hline Filler B & 7.00000 & 14 & 14 & & & & \\
\hline Metal detector & 0.00010 & 1 & 1 & 51,196 & 51,196 & 0.00 & 0.00 \\
\hline Capper & 0.25400 & 1 & 20 & 51,196 & 50,326 & 870 & 1.70 \\
\hline Sealing & 0.00010 & 1 & 1 & 50,326 & 50,326 & 0.00 & 0.00 \\
\hline Recapping & 0.25400 & 1 & 20 & 50,326 & 50,321 & 5.00 & 0.01 \\
\hline Labeler & 0.40000 & 1 & 16 & 50,321 & 48,559 & 1761 & 3.50 \\
\hline Top serter & 0.30000 & 1 & 20 & 48,559 & 45,063 & 3496 & 7.20 \\
\hline Check weigher & 0.00010 & 1 & 1 & 45,063 & 42,810 & 2253 & 5.00 \\
\hline $\begin{array}{l}\text { Bundling and } \\
\text { stretch band- } \\
\text { ing }\end{array}$ & 5.00000 & 24 & 24 & 42,810 & 42,810 & 0.00 & 0.00 \\
\hline
\end{tabular}

Table 2 Conveyors' characteristics

\begin{tabular}{|c|c|c|c|c|c|}
\hline Conveyor located between & Length (m) & $\begin{array}{l}\text { Capacity } \\
\text { (bottles) }\end{array}$ & Conveyor located between & Length $(\mathrm{m})$ & $\begin{array}{l}\text { Capacity } \\
\text { (bottles) }\end{array}$ \\
\hline Unscrambler, blower & 2.40 & 53 & Metal detector, capping & 4.60 & 102 \\
\hline Blower, distributer & 2.80 & 62 & Capping, sealing & 1.00 & 22 \\
\hline Distributer, filler A & 4.00 & 88 & Sealing, recapping & 3.80 & 84 \\
\hline Distributer, filler B & 4.00 & 88 & Recapping, labeling & 4.80 & 107 \\
\hline Filler $A$, station after filling & 3.40 & 75 & Labeling, top serting & 2.00 & 44 \\
\hline Filler B, station after filling & 3.40 & 75 & Top serting, check weigher & 2.60 & 55 \\
\hline Station after fillers and metal detector & 5.50 & 121 & Check weigher, bundling & 3.50 & 77 \\
\hline
\end{tabular}


Table 3 Sensors' characteristics

\begin{tabular}{lcl}
\hline Sensor located between & \multicolumn{2}{c}{ Sensor capacity } \\
\cline { 2 - 3 } & Minimum value & $\begin{array}{c}\text { Maxi- } \\
\text { mum } \\
\text { value }\end{array}$ \\
\hline Unscrambler, blower & 5 & 48 \\
Distributer, fillers & 18 & - \\
Fillers, metal detector & 12 & 109 \\
Metal detector, capping & 10 & 92 \\
Capping, sealing & 2 & 20 \\
Sealing, recapping & 2 & 76 \\
Recapping, labeling & 11 & 96 \\
Labeling, top serting & 4 & 40 \\
Top serting, check weigher & 5 & 50 \\
Check weigher, bundling & 7 & 70 \\
\hline
\end{tabular}

Table 4 Simulation results for filling line (As-Is model)

\begin{tabular}{lcll}
\hline Measure & Expected & Actual & Error (\%) \\
\hline Average input & 53,437 & 52,188 (bottle) & 2.33 \\
Average output & 47,016 & 45,000 (bottle) & 4.28 \\
Work in process (WIP) & 6563 & 6682 (bottle) & 1.81 \\
Average waiting time & 1908 & $1912(\mathrm{~s})$ & 0.20 \\
\hline
\end{tabular}

output values were compared with their corresponding actual values as shown in Table 4. For example, the expected total number of bottles entered to the system is about 53,437 bottles, while the actual number of bottles is 52,188 bottles. It is found that largest error percentage (\%) does not exceed $5 \%$. Hence, simulation model is concluded reliable and can be further used to conduct improvement analysis. Further, the overall OEE is calculated as follows. The scheduled time $(=390 \mathrm{~min}-90 \mathrm{~min}=300 \mathrm{~min})$ is the shift Length minus the breaks. Then, the operating time (=300 $\mathrm{min}-0 \mathrm{~min}=300 \mathrm{~min}$ ) is equal to scheduled time minus down time. Accordingly, availability is calculated and found equal to $100 \%$ (= (300 $\mathrm{min} / 300 \mathrm{~min}) \times 100 \%)$. Further, number of good bottles $(=53,437-6421=47,016)$ bottles is equal to the total number of produced bottles minus defective one. Consequently, the performance $(=[47,016 / 300) / 157$ bottle/min) $])$ and quality (= Good pieces/total pieces) are calculated and found equal to $99.82 \%$ and $87.98 \%$, respectively. Finally, the OEE is calculated and found equal to $87.83 \%(=(1.00 \times 0.9982 \times 0.879$ $8) \times 100 \%)$. In a similar manner, the OEE scores are calculated for all machines of the filling lines and the results are displayed in Table 5.

Comparing between the OEE scores and the world-class values in Table 5, it is clear that three machines possess OEE scores smaller than the word class values, including the labeler, top serter, and check weigher machines. The labeler machine corresponds to the lowest OEE percentage $(=67.80 \%)$; due to bar code visibility problem which leads to low performance $(P=78.70 \%)$. The second lowest OEE score $(=83.12 \%)$ corresponds to the top serter machine has an OEE percentage of, because of its poor performance $(P=86.85 \%)$ that is affected by labeler machine. Finally, the third lowest OEE $(=81.2 \%)$ score corresponds to the check weigher, which is caused by poor performance $(P=87.99 \%)$ and quality problems $(Q=92.00 \%)$. Consequently, agile and lean practices should be employed to enhance the performance of these processes.

\subsubsection{In phase II}

Alternatives of lean and agile practices are suggested to enhance the filling processes. Four agile scenarios shown in Fig. 7 are proposed including: A1: Adding a WIP buffer

Table 5 The OEE values for all machines (As-ls model)

\begin{tabular}{lllllll}
\hline Machine name & Availability (\%) & Performance (\%) & Quality (\%) & OEE value (\%) & World class (\%) & Suggested action \\
\hline Unscrambler & 100.00 & 89.79 & 100.00 & 89.79 & 85.00 & No improvement \\
Blower & 100.00 & 89.87 & 100.00 & 89.77 & 85.00 & No improvement \\
Fillers & 100.00 & 96.69 & 99.00 & 95.72 & 85.00 & No improvement \\
Metal detector & 100.00 & 88.17 & 98.00 & 86.45 & 85.00 & No improvement \\
Capper & 100.00 & 88.03 & 100.00 & 88.00 & 85.00 & No improvement \\
Sealing & 100.00 & 86.52 & 98.00 & 85.04 & 85.00 & No improvement \\
Recapper & 100.00 & 86.52 & 100.00 & 86.58 & 85.00 & No improvement \\
Labeler & 100.00 & 78.70 & 86.00 & 67.80 & 85.00 & Needs improvement \\
Top serter & 100.00 & 86.85 & 96.00 & 83.12 & 85.00 & Needs improvement \\
Check weigher & 100.00 & 87.99 & 92.00 & 81.27 & 85.00 & Needs improvement \\
Bundling and & 100.00 & 98.68 & 100.00 & 98.59 & 85.00 & No improvement \\
\multicolumn{1}{c}{ stretch banding } & & & & & \\
\hline
\end{tabular}




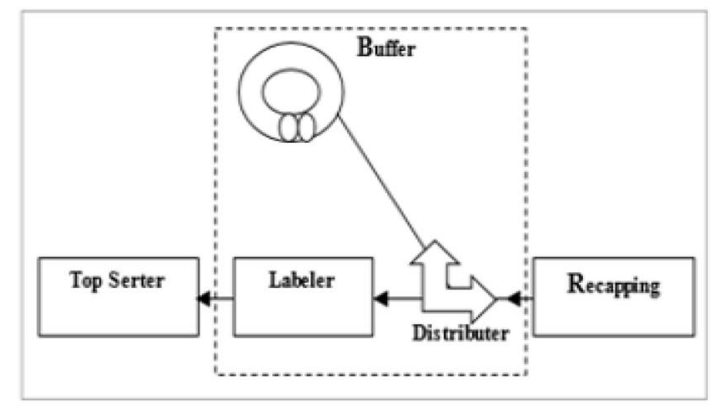

(a) Buffer (A.1).

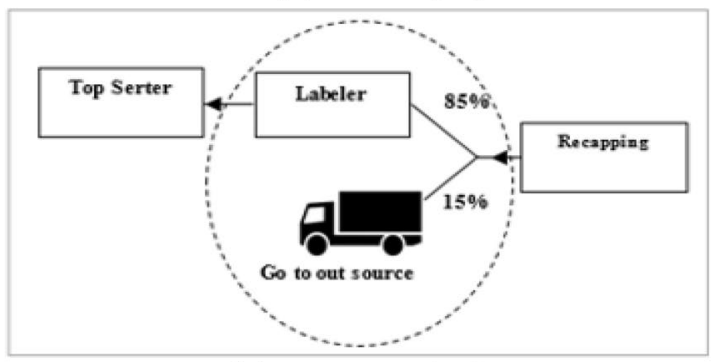

(c) Outsource (A3).

Fig. 7 Suggested agile practices

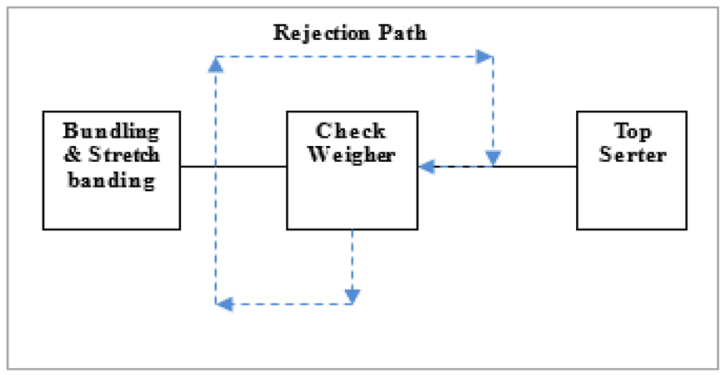

(a) Rework after check weigher (L1).

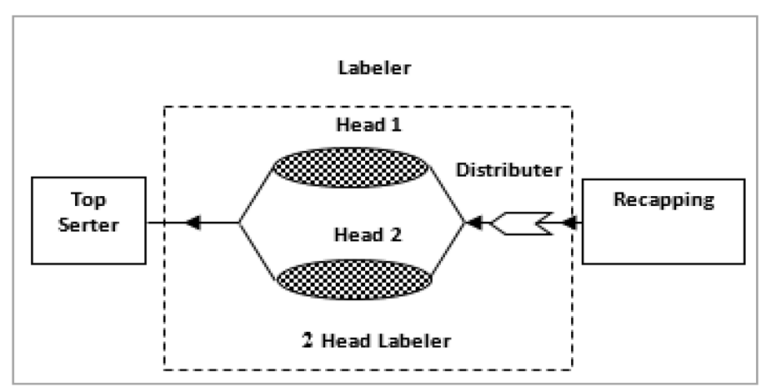

(c) Additional head to the labelet (L3).

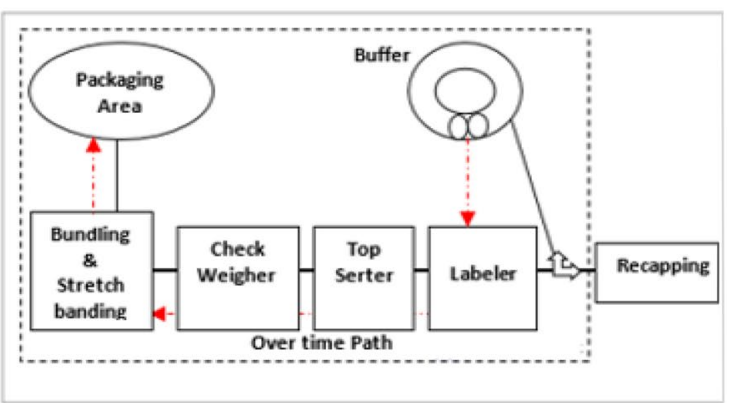

(b) Overtime (A2).

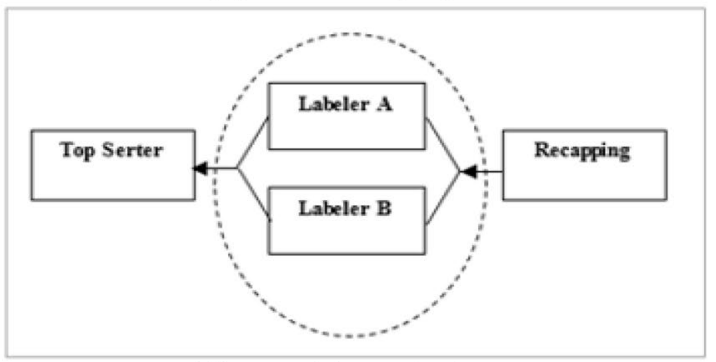

(d) New labeler (A4)

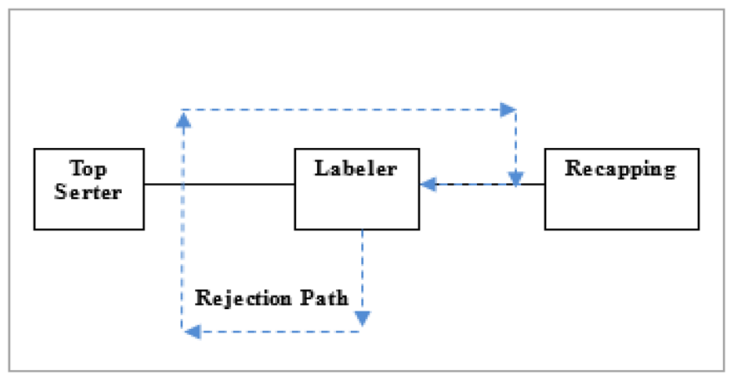

(b) Rework afterlabeler (L2).

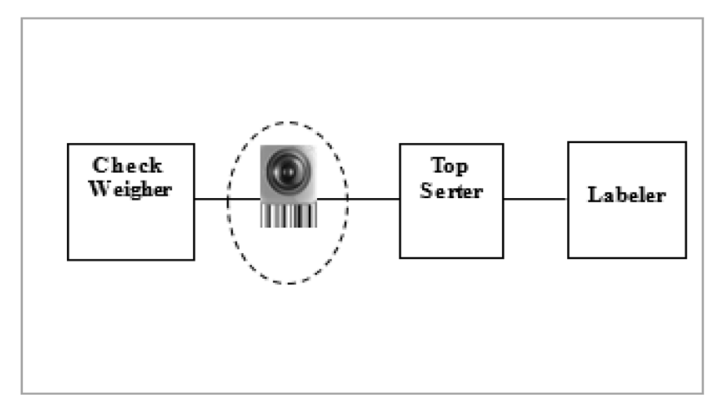

(d) Using a barcode cam era (L4).

Fig. 8 Suggested lean practices

before labeler, A2: Adding a WIP buffer before labeler plus working over time to label bottles in the buffer.

A3: suggests outsource for a percentage of $15 \%$ of labeled bottles, and A4: adds a new identical labeler machine. On the other hand, four lean practices as shown in Fig. 8 are considered involving: L1: Reworking rejected bottles of check weigher machine, L2: Reworking the rejected bottles of labeler machine, L3: Adding 
Table 6 Feasibility matrix of agile and lean practices' combinations

\begin{tabular}{lll}
\hline Lean & \multicolumn{2}{l}{ Agile } \\
\cline { 2 - 3 } & A1 buffer (\%) & A2 over time (\%) \\
\hline $\begin{array}{lll}\text { L1: Rework check weigher rejec- } \\
\text { tion }\end{array}$ & 92.61 & 97.82 \\
L2: Rework labeler rejections & 89.95 & 99.35 \\
$\begin{array}{l}\text { L3: Add parallel header } \\
\text { L4: Using a barcode camera } \\
\quad \text { sensor }\end{array}$ & 99.71 & - \\
\hline
\end{tabular}

another head to the labeler machine, and L4: Installing a bar code camera sensor between check weigher and top serter machines to control barcode distance, angles, and orientation.

The To-Be simulation model for each alternative is run for a shift length of one batch and repeated ten times, where the results showed that the values of coefficient of variations are very small $(<0.01)$. Further, several applicable leagile combinations are considered as shown in Table 6. Simulation for each To-Be simulation of leagile model was conducted in a similar manner, where it is found that the leagile combination $(L 2, A 2)$ is the most cost-effective and results in high OEE score of $99.35 \%$. Table 7 displays the estimated average of To-Be simulation output measures for the alternatives of agile (A1-A4), lean (L1-L4), and the leagile $(L 2, A 2)$ practices.

\subsubsection{In phase III}

Ten improvement alternatives shown in Table 7, including the As-Is condition, will be evaluated with respect to averages of input bottles, cycle time, WIP, waiting time, OEE\%, and output bottles. Each alternative of agile, lean, and leagile practices, including the As-Is condition, is treated as a decision making unit (DMU) with averages of input bottles, cycle time, work-in-process (WIP), and waiting time are set as the inputs to be reduced, whereas OEE and average output bottles are outputs for all DMUs as also shown in Table 7. Then, the SBM is solved to estimate the efficiency score and rank of each of the ten alternatives. It is found that only $\mathrm{DMU}_{8}(\mathrm{~L} 3)$ and $\mathrm{DMU}_{10}(\mathrm{~A} 1-\mathrm{L} 2)$ are SBMefficient (efficiency score $=1$ ).

\section{Results and discussion}

Table 8 displays the resulted projection (Proj.) differences (Diff. \%) and efficiency scores using SBM. For illustration, for DMU3 to become efficient the averages of input bottles, cycle time, WIP, and waiting time have to be reduced from the projected values by $2.711 \%, 90.59 \%, 97.614 \%$, and $97.214 \%$, respectively. However, the average output bottles should be increased by $10.221 \%$.

To discriminate between the two SBM-efficient DMUs, the super-SBM is solved for each alternative and then the efficiency results are also listed in Table 9. It is found that $\mathrm{DMU}_{8}$ is the most efficient DMU (super-SBM efficiency $=1.012016$ ). Table 9 also displays the input and output slacks using SBM, where it is found that $\mathrm{DMU}_{8}$ results in excesses in average input bottles $\left(\mathrm{S}_{1}{ }^{-}\right)$, waiting time $\left(\mathrm{S}_{2}{ }^{-}\right)$, WIP $\left(\mathrm{S}_{3}{ }^{-}\right)$and waiting time $\left(\mathrm{S}_{4}{ }^{-}\right)$of 6.018054 , $0.133009,2.018355$, and 0.250802 , respectively. Moreover, the shortages $\mathrm{S}_{1}^{+}$and $\mathrm{S}_{2}^{+}$in OEE and average output are both equal to zero. Consequently, the most preferable improvement alternative is to the third lean practice (L3), which suggests adding another head to the labeler machine. The anticipated performance improvement in filling processes compared to As-Is condition are calculated and then displayed in Table 10.
Table 7 Estimated averages of To-Be simulation output measures

\begin{tabular}{llllllll}
\hline DMU & Alternative & $\begin{array}{l}\text { Input (1) } \\
\text { Average } \\
\text { input (bot- } \\
\text { tle) }\end{array}$ & $\begin{array}{l}\text { Input (2) } \\
\text { Cycle time (s) }\end{array}$ & $\begin{array}{l}\text { Input (3) } \\
\text { WIP (bottle) }\end{array}$ & $\begin{array}{l}\text { Input (4) } \\
\text { Average } \\
\text { waiting time } \\
\text { (s) }\end{array}$ & $\begin{array}{l}\text { Output (1) } \\
\text { OEE (\%) }\end{array}$ & $\begin{array}{l}\text { Output (2) } \\
\text { Average out- } \\
\text { put (bottle) }\end{array}$ \\
\hline 1 & Current & 53,437 & 2011.70 & 6563 & 1908 & 87.83 & 47,016 \\
3 & A1 & 53,427 & 275 & 6573 & 241 & 86.38 & 47,021 \\
2 & A2 & 55,519 & 1197 & 4481 & 205 & 97.17 & 53,992 \\
4 & A3 & 57,766 & 720 & 2234 & 616 & 96.23 & 55,670 \\
5 & A4 & 60,000 & 30 & 183 & 8 & 99.70 & 59,823 \\
6 & L1 & 53,451 & 2019 & 6549 & 1904 & 92.64 & 49,788 \\
7 & L2 & 53,469 & 2011 & 6531 & 1898 & 90.13 & 48,667 \\
8 & L3 & 60,000 & 29.87 & 181 & 7.75 & 99.71 & 59,825 \\
9 & L4 & 53,470 & 2012 & 6530 & 1898 & 87.92 & 50,131 \\
10 & A2-L2 & 56,000 & 1203 & 4000 & 209 & 99.35 & 55,640 \\
\hline
\end{tabular}


Table 8 Projection and efficiency scores using SBM

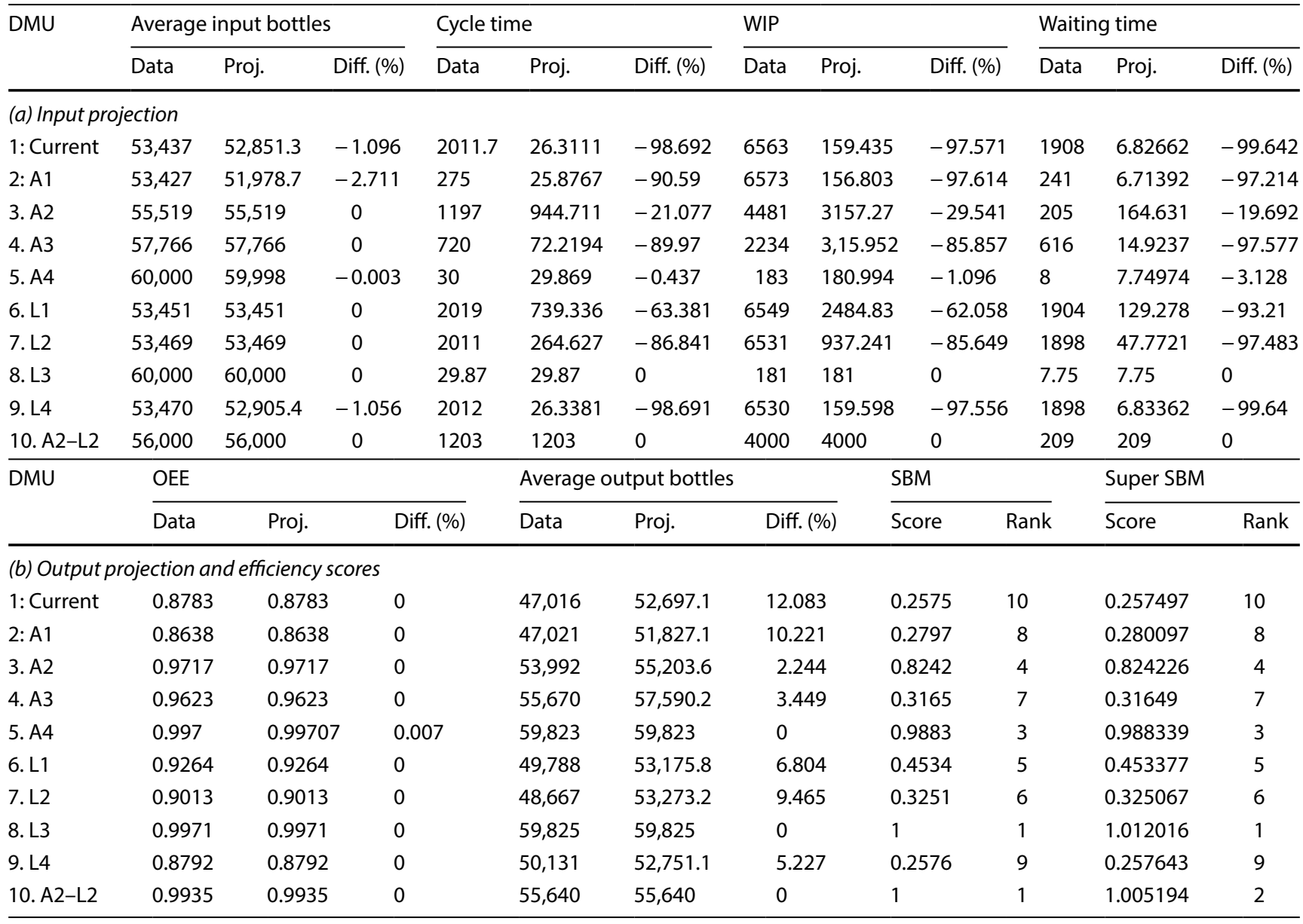

Table 9 Estimated scores, input, and output slacks using super-SBM

\begin{tabular}{llllllll}
\hline DMU & Score & $\begin{array}{l}\mathrm{S}_{1}^{-} \text {: excess } \\
\text { Average input }\end{array}$ & $\begin{array}{l}\mathrm{S}_{2}^{-} \text {: excess } \\
\text { Cycle time }\end{array}$ & $\begin{array}{l}\mathrm{S}_{3}^{-} \text {: excess } \\
\text { WIP }\end{array}$ & $\begin{array}{l}\mathrm{S}_{4}^{-} \text {: excess } \\
\text { Waiting time }\end{array}$ & $\begin{array}{l}\mathrm{S}_{1}^{+} \text {: shortage } \\
\text { OEE }\end{array}$ & $\begin{array}{l}\mathrm{S}_{2}^{+} \text {: shortage } \\
\text { Average output }\end{array}$ \\
\hline 1: Current & 0.257497 & 585.7313 & 1985.389 & 6403.565 & 1901.173 & 0 & 5681.119 \\
2: A1 & 0.280097 & 1443.048 & 249.008 & 6414.449 & 234.0688 & 0 & 4809.599 \\
3. A2 & 0.824226 & 0 & 252.2886 & 1323.729 & 40.3688 & 0 & 1211.59 \\
4. A3 & 0.31649 & 0 & 647.7806 & 1918.048 & 601.0763 & 0 & 1920.242 \\
5. A4 & 0.988339 & 2.00585 & 0.130999 & 2.006051 & 0.250259 & $6.67 \mathrm{E}-05$ & 0 \\
6. L1 & 0.453377 & 0 & 1279.664 & 4064.166 & 1774.722 & 0 & 3387.82 \\
7. L2 & 0.325067 & 0 & 1746.373 & 5593.759 & 1850.228 & 0 & 0 \\
8. L3 & 1.012016 & 6.018054 & 0.133009 & 2.018355 & 0.250802 & 0 & 0 \\
9. L4 & 0.257643 & 564.5743 & 1985.662 & 6370.402 & 1891.166 & 0 & 0 \\
10. A2-L2 & 1.005194 & 1163.44 & 0 & 0 & 0 & 0 & 2620.118 \\
\hline
\end{tabular}

From Table 10, it found that adding another head to the labeler machine results in increasing the ratio of the average output to input is from 87.98 to $99.71 \%$ and reducing the averages of cycle time, WIP, and waiting time by 98.52\%, 97.24\%, and 99.59\%, respectively. Moreover, the OEE score is increased by $13.53 \%$. Definitely, such improvement in process performance are sufficient to justify investment costs and results in significant savings in production and quality costs. 
Table 10 Estimated improvement

\begin{tabular}{llllllll}
\hline Alternative & Input bottles & Cycle time & WIP & waiting time & OEE & Output bottles & Output/input (\%) \\
\hline Current condition (1) & 53,437 & 2011.7 & 6563 & 1908 & $87.83 \%$ & 47,016 & 87.98 \\
$\begin{array}{l}\text { L3: Adding another head } \\
\text { to labeler machine (2) }\end{array}$ & 60,000 & 29.87 & 181 & 7.75 & $99.71 \%$ & 59,825 & 99.71 \\
$\begin{array}{l}(3)=(1)-\mathrm{T}(2) \\
(4)=(3) /(1) \%\end{array}$ & 6563 & -1981.83 & -6382 & -1900.25 & 0.1188 & 12,809 \\
\hline
\end{tabular}

\section{Conclusions}

This research aims at improving the performance of the filling processes in a pharmaceutical industry with six simulation output measures of main interest, including averages of cycle time, average input bottles, average output bottles, average waiting time, WIP and OEE. Firstly, the As-Is simulation was built and run, where the results showed that the Labeler, Top Serter, and Check Weigher machines need improvement $(\mathrm{OEE}<85 \%)$. Nine To-Be simulation alternatives utilizing agile and/or lean practices were identified and assessed using simulation. To determine the best alternative, each alternative is treated as a DMU with four inputs and two outputs. The SBM in DEA was then employed to evaluate the efficiency score and determine the corresponding rank of each alternative. Results showed that the lean practice; adding another head to the labeling machine, is the best alternative by which the OEE score is increased by $13.53 \%$ from that found at the As-Is condition. In practice, such improvement results in huge savings in production as well as quality costs. In conclusion, agile and lean practices turn to be effective tools in improving performance of the filling processes in the studied pharmaceutical industry. Moreover, the SBM in DEA is found an effective DEA technique that enables decision makers in pharmaceutical industry in identifying the best improvement practice.

\section{Compliance with ethical standards}

Conflict of interest The authors declare that they have no conflict of interest.

\section{References}

1. Singla A, Ahuja IS, Sethi AS (2017) An examination of effectiveness of demand pull practices for accomplishing sustainable development in manufacturing industries. J High Technol Manag Res 28(2):142-158
2. Haleem RM, Salem MY, Fatahallah FA, Abdelfattah LE (2015) Quality in the pharmaceutical industry: a literature review. Saudi Pharm J 23(5):463-469

3. Gunasekaran A (1999) Agile manufacturing: a framework for research and development. Int J Prod Econ 62(1-2):87-105

4. Gunasekaran A (1998) Agile manufacturing: enablers and an implementation framework. Int J Prod Econ 36(5):1223-1247

5. Sanchez LM, Nagi R (2001) A review of agile manufacturing systems. Int J Prod Econ 39(16):3561-3600

6. Cho H, Jung M, Kim M (1996) Enabling technologies of agile manufacturing and its related activities in Korea. Comput Ind Eng 30(3):323-334

7. Sharp JM, Irani Z, Desai S (1999) Working towards agile manufacturing in the UK industry. Int J Prod Econ 62(1-2):155-169

8. Perry M, Sohal AS, Rumpf P (1999) Quick response supply chain alliances in the Australian textiles, clothing and footwear industry. Int J Prod Econ 62(1-2):119-132

9. Gonzalez-Benito J (2000) Effect of the characteristics of the purchased products in JIT purchasing implementation. Int J Oper Prod Manag 22(7):868-886

10. Besterfield DH (2013) Quality improvement, 9th edn. Pearson, London

11. Malhotra IS (2006) Moving and controlling the flow of quality. Qual Prog 2006:67-69

12. Ledón RA, Luján-García DE, Garrido-Vega $P$, Escobar-Pérez $B$ (2018) A meta-analytical study of the impact of lean practices on firm performance. Int J Prod Econ. https://doi.org/10.1016/j. ijpe.2018.03.015

13. Bhamu J, Singh Sangwan K (2014) Lean manufacturing: literature review and research issues. Int $J$ Oper Prod Manag 34(7):876-940

14. Demeter K, Matyusz Z (2011) The impact of lean practices on inventory turnover. Int J Prod Econ 133(1):154-163

15. Womack JP, Jones DT (1997) Lean thinking — banish waste and create wealth in your corporation. J Oper Res Soc 48(11):1148

16. Christopher M, Lowson R, Peck H (2004) Creating agile supply chains in the fashion industry. IJ Retail Distrib Manag 32:367-376

17. Naylor JB, Naim MM, Berry D (1999) Leagility: integrating the lean and agile manufacturing paradigms in the total supply chain. Int J Prod Econ 62(1-2):107-118

18. Bruce M, Daly L, Towers N (2004) Lean or agile: a solution for supply chain management in the textiles and clothing industry? Int J Oper Prod Manag 24(2):151-170

19. Naylor JB, Naim MM, Berry D (1999) Leagility: integrating the lean and agile manufacturing paradigms in the total supply chain. Int J Prod Econ 62(1/2):107-118

20. Puvanasvaran P, Teoh YS, Tay CC (2013) Consideration of demand rate in overall equipment effectiveness (OEE) on equipment with constant process timell. J Ind Eng Manag 6(2):507-524

21. Puvanasvaran AP, Mei CZ, Alagendran VA (2013) Overall equipment efficiency improvement using time study in an aerospace 
industry: The Malaysian international tribology conference 2013, MITC. Procedia Eng 68:271-277

22. Dal B, Tugwell P, Greatbanks R (2000) Overall equipment effectiveness as a measure of operational improvement: a practical analysis. Int J Oper Prod Manag 20(12):1488-1502

23. Hansen RC (2001) Overall equipment effectiveness: a powerful production/maintenance tool for increased profits. Industrial Press Inc, Norwalk

24. Bamber CJ, Castka P, Sharp JM, Motara Y (2003) Cross-functional team working for overall equipment effectiveness (OEE). J Qual Maint Eng 9(3):223-238

25. Becker JMJ, Borst J, van der Veen A (2015) Improving the overall equipment effectiveness in high-mix-low-volume manufacturing environments. CIRP Ann 64(1):419-422

26. Charnes A, Cooper WW, Rhodes E (1978) Measuring the efficiency of decision making units. Eur J Oper Res 2(6):429-444

27. Al-Refaie A, Najdawi R, Sy E (2016) Using DEA window analysis to measure the efficiencies of blowing machines in plastics industry. Jordan J Mech Ind Eng 10:27-38

28. Seiford LM, Thrall RM (1990) Recent developments in DEA: the mathematical programming approach to frontier analysis. J Econom 46(1-2):7-38

29. Mogha SK, Yadav SP, Singh SP (2016) Estimating technical efficiency of public sector hospitals of Uttarakhand (India). Int J Oper Res 25(3):371-399

30. Mogha SK, Yadav SP, Singh SP (2015) Slack based measure of efficiencies of public sector hospitals in Uttarakhand (India). Benchmarking Int J 22(7):1229-1246

31. Mogha SK, Yadav SP, Singh SP (2014) Estimating technical and scale efficiencies of private hospitals using a non-parametric approach. Int J Oper Res 20(1):21-40

32. Sohal AS, Egglestone A (1994) Lean production: experience among australian organizations. Int J Oper Prod Manag 14(11):35-51

33. Bonavia T, Marin JA (2006) An empirical study of lean production in the ceramic tile industry in Spain. Int J Prod Manag 26(5):505-531

34. Mahapatra SS, Mohanty SR (2007) Lean manufacturing in continuous process industry: an empirical study. J Sci Ind Res 66:19-27

35. Wong YC, Wong KY, Ali A (2009) A study on lean manufacturing implementation in the Malaysian Electrical and Electronics Industry. Eur J Sci Res 38(4):521-535

36. Ferdousi F, Ahmed A (2009) An investigation of manufacturing performance improvement through lean production: a study on Bangladeshi garment firms. Int J Bus Manag 4(9):106-116
37. Yogesh M, Chandra Mohan G, Arrakal R (2012) Application of lean in a small and medium enterprise (SME) segment: a case study of electronics and electrical manufacturing industry in India. Int J Sci Eng Res 3(8):1-8

38. Devakim MP, Jayanthi R (2014) Barriers to implementation of lean principles in the Indian construction industry. Int J Eng Res Technol 3(5):1189-1192

39. Khlat M, Harb AH, Kassem A (2014) Lean manufacturing: implementation and assessment in the Lebanese pharmaceutical industry. Int J Comput Optim 1:47-62

40. Hu Q, Mason R, Williams SJ, Found P (2015) Lean implementation within SMEs: a literature review. J Manuf Technol Manag 26(7):980-1012

41. Kafuku JM (2019) Factors for effective implementation of lean manufacturing practice in selected industries in Tanzania. Procedia Manuf 33:351-358

42. Gunasekaran A, Tirtiroglu E, Wolstencroft V (2002) An investigation into the application of agile manufacturing in an aerospace company. Technovation 22(7):405-415

43. Vázquez-Bustelo $D$ (2006) Agile manufacturing: industrial case studies in Spain. Technovation 26(10):1147-1161

44. Francisco LR, Manuela T (2010) Exploring agile methods in construction small and medium enterprises: a case study. J Enterp Inf Manag 23(2):161-180

45. Zhang DZ (2011) Towards theory building in agile manufacturing strategies-case studies of an agility taxonomy. Int J Prod Econ 131(1):303-312

46. Iqbal T, Huq F, Khurrum M, Bhutta S (2018) Agile manufacturing relationship building with TQM, JIT, and firm performance: an exploratory study in apparel export industry of Pakistan. Int J Prod Econ 203:24-37

47. Fritzsche A (2018) Implications of agile manufacturing in the automotive industry for order management in the factoriesevidence from the practitioner's perspective. Procedia CIRP 72:369-374

Publisher's Note Springer Nature remains neutral with regard to jurisdictional claims in published maps and institutional affiliations. 